\title{
Researching forced migrants' trajectories: encounters with multilingualism
}

\author{
Erika Kalocsányiová
}

\begin{abstract}
This contribution is concerned with the impact of multilingualism on forced migrants' trajectories. Drawing on a corpus of linguistic ethnographic data that was collected over a two-year period, it focuses on the experiences of two individuals who were granted international protection in Luxembourg. Key events and anecdotes are used to reconstruct their sociolinguistic trajectories, learning histories, and mobile aspirations before and after settling in the Grand Duchy. Despite having similar linguistic repertoires, "Ahmad" and "Patrick" reported disparate experiences. This chapter provides unique insights into how linguistic integration is understood and experienced in multilingual societies.
\end{abstract}

\section{Keywords}

Repertoires and trajectories, forced migration, multilingualism, linguistic integration, (im)mobility

\section{Introduction}

Investigating border experiences is a continuing concern in sociolinguistic studies. Borders represent a crucial angle from which to examine the many ways in which mobility intersects with nation-state politics of language and integration. Migration/displacement across borders entails a change in the linguistic environment with whose practices, discourses, and rules a person is familiar (cf. Busch 2017). Language thus constitutes a powerful means of self-affirmation in new sociocultural milieus. Given its rich migration history, the Grand Duchy of Luxembourg provides a fascinating setting for exploring how individuals (re)create, sustain, and contest borders through languages. New arrivals to Luxembourg are expected to integrate into a society that is structured around the widespread circulation of people and their linguistic repertoires. This raises crucial questions: What are the politics of language and integration in settings of complex linguis- 
tic diversity? How do these policies shape and/or inflect immigrants' sociolinguistic trajectories? What types of individual trajectories emerge? This chapter addresses each of these questions in more detail. More specifically, it focuses on the struggles and accomplishments of two men, Ahmad and Patrick (pseudonyms), who sought refuge in Luxembourg. The chapter builds on the findings of a two-year ethnographic research project that addressed the impact of multilingualism on forced migrants' trajectories. The use of the term "forced migrant" in this context is meant to acknowledge both refugees and people who are forced to migrate due to factors that are not spelled out by the 1951 Refugee Convention (e.g. conflicts, natural or environmental disasters, famine, broader human rights violations, and development projects).

The first subchapter is devoted to the relationship between language, migration, and national borders (cf. Canagarajah 2017; Van Avermaet 2009; Newman 2006; Stevenson 2006). Next, a summary of major methodological influences is provided (cf. Busch 2017; Juffermans/Tavares 2017, Stevenson 2014). The section concludes with a brief overview of the sociolinguistic situation and integration debates in Luxembourg. The purpose of the second subchapter is to describe the research methods used and to contextualize the participants' stories. In part three, key events are used to reconstruct the research participants' language (hi)stories vis-à-vis their migration experience to Luxembourg, their learning trajectories in their new sociolinguistic environment(s), and their future mobile aspirations. The chapter ends with a discussion and concluding remarks.

\section{Language, migration, and the nation state}

The language-migration nexus has recently attracted considerable attention: in parallel to what Faist (2013) described as the "mobility turn", the last decade also saw a substantial proliferation of scholarly work devoted to the intersection of language, borders, and human (im)mobility (cf. Canagarajah 2017). To index the forms of communication and contact that transcend bounded, territorialized, and separated languages, scholars have adopted multiple terms, some of which are "translanguaging" (cf. Creese/ Blackledge 2010; García/Li Wei 2014), "metrolingualism” (cf. Otsuji/ Pennycook 2010), "polylingualism" (cf. Jørgensen et al. 2011), and "truncated multilingualism" (cf. Blommaert 2010). This body of research drew attention to, among other things, the complex patterns of language use that arise as people move across borders and spaces where multiple languages are in use. While there is a growing acknowledgement of migra- 
tion-driven diversity in Europe, commonly discussed under the rubric of super-diversity (cf. Vertovec 2007), linguistic integration studies are still largely shaped by ethno-national approaches (cf. Grzymala-Kazlowska/ Phillimore 2018) and methodological nationalism (cf. Glick Schiller 2009). In policy terms, there are many indications of essentializing tendencies, evidenced by the new (or renewed) language requirements that multiple EU member states have imposed on those seeking citizenship, residency or even entrance to their territories (cf. Van Avermaet 2009). Arguments asserting that insufficient knowledge of state-mandated/national languages constitutes an obstacle to integration and is a cause of violence and social conflict often go uncontested. Meanwhile, the real-life complexities faced by forced migrants seeking asylum across Europe remain an under-researched area.

Linguistic differences have traditionally served as means of creating a sense of distinction between the "us here" and the "them there". In Burke's view, the social changes of the late eighteenth century turned language into an "instrument of the cult of the nation", which "both expresses and helps to create national communities" (2004, p. 171). By way of illustration, let us consider the example of the Grand Duchy of Luxembourg. The symbolic boundaries between nineteenth-century Luxembourg and its larger neighbors were established through distinctive patterns of language use, i.e. the use of German and French as written languages along with the spoken use of one distinctive code, currently known as Luxembourgish. This boundary-drawing mechanism has been exploited to legitimize the existence of independent Luxembourg for two centuries (cf. Horner/Weber 2008 , p. 85). Sociolinguistic and linguistic anthropological research has long recognized language as a powerful (semiotic) resource implicated in processes of group formation (cf. Heller 1987) as well as the construction of identities and the delimitation of space (cf. Irvine/Gal 2002). Another fundamental aspect of language is "its capacity for generating imagined communities, building in effect particular solidarities" (Anderson 1991, p. 133).

Despite the intensification of migration flows that cut across borders and continents, linguistic traits continue to play a key role in constructing and maintaining multiple boundaries; being unable to speak a particular language (or combination of languages) places restrictions on one's ability to communicate and-by extension - to identify with any territorial, ethnic, and/or national identities that language is associated with. For the eminent theorist of borderlands, David Newman, language "remains the one great boundary which, for so many of us, remains difficult to cross, in the absence of a single, global, borderless form of communication" (2006, p. 
148). Linguistic differences are often drawn upon to rationalize (im)mobility, and, as Park (2014, p. 84) has pointed out, "it is through language that people on the move imagine and construct themselves as migrants." It is also important to remember that, in the context of the intensifying commodification of languages (cf. Heller 2010), language is increasingly seen as an economic/marketable resource that immigrants can acquire like any other skill (cf. Duchêne/Heller 2012). Entire projects of mobility within and across national borders often come to be structured around complex networks of ideological associations between different language(s) and spaces. An example of this phenomenon is discussed in Gogonas and Kirsch's paper (2016) about Greek migrant families in Luxembourg.

Adopting the perspective of super-diversity, numerous scholars of multilingualism - some of whom were mentioned earlier-have disputed the alleged "boundedness" of languages and made visible the fluidity and messiness of everyday languaging. According to Silverstein (2014), their observations challenge and test the states' organizational flexibility to encompass and control one or more language communities in which the people within their borders participate. Since the mid-1990s, the politicization of migration has set in motion a series of amendments to residency, citizenship, and immigration laws. The prominent position of language among these new standards has led some observers to interpret this trend as "linguistic nationalism" (cf. Stevenson 2006). A growing body of research conducted in this field has linked languages to re-bordering processes across Europe (cf. Baba/Dahl-Jørgensen 2013; Van Avermaet/Rocca 2013). As Shohamy (2006) explains, in the integration machinery, the willingness to learn and use the dominant language(s) is regarded as an indicator of loyalty, belonging, inclusion, and membership. Despite the focus on language, these reflections do not claim that language is the sole variable in the equation; it is, however, a powerful means through which forced migrants (could) reflect, position, and affirm themselves in their old/new sociocultural milieus.

Research into super-diverse environments is not well served with a priori notions of "language", "native speaker", and "mother tongue". Instead, sociolinguists-especially in linguistic ethnography-now generally work with the notion of linguistic repertoires. As explained by Blommaert and Backus (2013), repertoires bear traces of a person's biography, reflecting the spaces, niches, and networks in which s/he has operated. For Busch, who also revisited the concept recently $(2012 ; 2017)$, a linguistic repertoire "not only points backward to the past of the language biography, which has left behind its traces and scars, but also forward, anticipating and projecting the future situations and events we are preparing to face" (2017, p. 
356). Repertoires are therefore as much indexes of people's pasts as of their aspirations/desire for mobility (cf. Carling/Collins 2018). In her latest contribution to the debate, Busch (2017) is concerned with the relationship between individual life stories and what she defines as Spracherleben or "the lived experience of language". Her approach builds on a speaker-centered biographical perspective, which I adopt here in order to investigate how experiences of linguistic inequality/success are imprinted on forced migrants' repertoires, both in the form of explicit and implicit language attitudes and changed patterns of language use. I have also drawn inspiration from Juffermans and Tavares's (2017) research on south-north trajectories and linguistic repertoires; their work rests on a trajectory approach to migration and language which "attempts to makes sense of the practical and cognitive challenges, structural and agentive forces, and the changing subject positions in individual projects of (trans)migration, after, during, and before migration" (p. 104, emphases in original). A major methodological influence was research into the sociolinguistics of narrative (cf. de Fina/ Tseng 2017) and Stevenson's work on language (hi)stories (2014; 2017). Accordingly, the accounts given by participants in my research are not analyzed as chronological histories but as narrations of (im)mobile and multilingual selves.

Questions of language are of fundamental importance to integration debates in Luxembourg. The Grand Duchy has the highest proportion of foreign-born population in the EU: non-Luxembourgish passport holders account for 47.8 percent of the total population of 602,005 (as of January 1, 2018; cf. STATEC 2018a); in addition, the country employs about 188,000 cross-border workers from France, Belgium, and Germany (cf. STATEC 2018b). Cross-border workers and migrants alike have brought new repertoires and practices to an already complex sociolinguistic environment, "making everyday communication in Luxembourg a highly diverse and dynamic affair" (Franziskus 2016, p. 207). Since languages are a primary factor in structuring the local labor market (Pigeron-Piroth/Fehlen 2015), the speakers of the various languages have interests to protect (de Bres 2014).

The above figures are central to understanding the specific linguistic ideas that are associated with "Luxembourgishness". Using media and government sources, Horner and Weber (2008) distinguished between two main strategies of linguistic identification: the "trilingual ideal", which entails mastery of the three languages recognized by the Language Act of 1984 (Luxembourgish/German/French), and a "monolingual identification" rooted (solely) in the Luxembourgish language. In Horner's view (2009, p. 149), these two strategies have been positioned in both complementary and conflictual relationships, "with the conflictual scenario gain- 
ing momentum since the 1970s". This shift coincided with Luxembourg's increasing reliance on immigrant and cross-border labor (cf. Beine/Souy 2016) as well as with initial attempts to foster a sense of collective European identity (cf. OP 1973). The accompanying sociolinguistic changesreflected in the increased use of (mainly) French-stirred up discontent among some Luxembourgish nationals. Mounting concerns over the preservation of the Luxembourgish language led to the gradual implementation of language requirements and testing procedures for naturalization. Since the early 2000s, discourses of integration have positioned Luxembourgish as "an instrument of civic participation" and "the solution to the perceived problem of augmented societal and linguistic heterogeneity" (Horner 2017, p. 53). Following the 2008 and 2017 revisions to the Nationality Act, individuals aspiring to citizenship must pass a Luxembourgish language test, regardless of their proficiency in French or German, as well as a citizenship course. These measures resonate with similar forms of rebordering legislation in Europe.

\section{Methodological approach and research participants}

Let us now move to the specific research context. This chapter draws on a corpus of ethnographic data that was collected over a two-year period. The project, which is being carried out as part of a doctorate at the University of Luxembourg, was designed as an exploratory study to uncover the complexities that define forced migrants' linguistic integration efforts in multilingual societies. Previously, I examined structured language learning tasks and broader social interactions, concluding that a multilingual pedagogical orientation creates learning spaces that help forced migrants "to see the local languages as new functional resources in their growing repertoires", a necessary and important resource for navigating local life (Kalocsányiová 2017 , p. 489). The main ideological underpinnings of the integration discourse are discussed in a forthcoming publication (Kalocsányiová 2018). Here, I will focus on only two research participants, Ahmad and Patrick, both of whom applied for international protection in the Grand Duchy in 2015. Since the project's start in the spring of 2016, data collection has been dictated by the project participants' movement through different spaces, networks, and sites. Following an introductory meeting at which informed consent was obtained, the participants were invited to choose their own pseudonyms for the research. We agreed on the names "Ahmad" and "Patrick". Afterwards, I conducted narrative interviews-lasting approximately an hour - with each of them to elicit information about their 
repertoires, migration experiences, language learning goals, and language use in their new sociolinguistic environment. Since then, I have periodically interviewed them approximately every six months, using on occasion non-static techniques such as go-along, i.e. accompanied walks with interviewees as they go about their routines (cf. Kusenbach 2003, Lamarre 2013). In addition to formal interviews, the project also builds on information generated through informal interactions and everyday types of encounters between the researcher (me) and Ahmad or Patrick. Rodgers (2004, p. 49) refers to this approach as "hanging out" and endorses it as an ethically desirable research tool that opens a "channel for voices of forced migrants, without claiming to definitively represent them", and thus "sustain[s] a humanism in research." Ethnographic field notes and approximately 50 hours of audio-recorded interactions complement the data for this chapter.

In the following, I will present the two project participants and their language experiences prior to arriving in Luxembourg. At the time of recruitment, Ahmad was in his mid-twenties. He was born into a family of farmers in the district of Afrin in northern Syria, where he remained up until the outbreak of the armed conflict in 2012. He spoke Kurdish (Kurmanji) at home and with his childhood friends and neighbors. His mother was Lebanese; she could understand but not speak Kurdish. Because the Kurdish language was banned in schools, he received all his primary school education in Arabic. He completed nine years of schooling. Although English was part of the school curriculum, Ahmad attested to having learnt the language primarily through informal channels during his stay in Lebanon; in 2012, he fled with his family to Beirut, where he worked as an electrician for a while. As he recounts it, some of his coworkers were English speakers, and he felt he was an object of ridicule until his English skills improved. He migrated to Luxembourg following a complex route along the eastern Mediterranean route.

The second research participant, Patrick, is in his mid-thirties. He was born and raised in Kadhimiya, a northern neighborhood in Baghdad. After earning a degree in engineering, he worked at a power plant project funded by the US government in a remote region of southern Iraq. His workplace interactions included communication in both Arabic and English. For years, Patrick was eagerly looking for opportunities to expand his communicative repertoire; however, his attempts to learn French and Russian at an affordable price were fruitless. Prompted by his eagerness to learn foreign languages, he associated the efforts he had made with his aspirations for transnational mobility: "I wanted to learn these languages to maybe go to other countries and meet new cultures" (August 17, 2016). Af- 
ter members of his family were abducted and killed, Patrick left Iraq, fleeing first to Turkey and then to Europe, crammed on a dinghy with dozens of other people. He arrived in Luxembourg in the summer of 2015.

\section{Forced migrants' trajectories and experiences with language}

\subsection{Early days in the Grand Duchy}

Prior to them arriving in Luxembourg, the peculiarities of local multilingualism were unknown to both research participants. During our second meeting (September 17, 2016), Ahmad told an anecdote which exemplifies the initial confusion he experienced. In his imagination, Luxembourg was a German-speaking country: "I didn't know anything, I just thought it was like Germany." A couple of hours after his arrival, he and his travel companions overheard a conversation in (what they believed was) French at the refugee center. Driven by curiosity, Ahmad asked around among the other residents at the center, who gave him his first bits of information about Luxembourg's language environment. Once he corroborated that "French was everywhere", he asked in bewilderment, "What comes next?" In the local establishments, staffed (mainly) by Francophone cross-border workers, his initial attempts to communicate in English failed. His lack of familiarity with local practices, discourses, and rules became a source of discomfort. Busch (2017, p. 340) refers to similar episodes as "the underlying experience that one's own linguistic repertoire no longer fits," which, in her view, occurs not only in extreme situations but is shared by all speakers when experiencing dislocation. Shortly after presenting his asylum claim, Ahmad was relocated to Wiltz, a town of around 5,000 people in the north of the Grand Duchy. When characterizing Wiltz's linguistic texture, Ahmad alluded to a number of languages that, in addition to Luxembourgish and French, were embedded in the social fabric of local life. His accounts made frequent references to Portuguese speakers in his neighborhood, Kosovars and Bosnians in the local mosque, and Africans in his building. However, in the absence of strong social ties with the local population, the private spaces in his life remained almost exclusively monolingual (i.e. Arabic): “we don't have [a lot of] communication because we don't have French friends or Deutsche friends or any European friends [...] we just have Iraqi and Arab friends." (August 17, 2016).

Patrick's experiences diverged from Ahmad's. His earliest accounts did not invoke moments of linguistic failure; on the contrary, he talked about the multiplicity of local languages in almost utopian terms. He used to 
think that multilingualism was a sign and means of cultural reconciliation, and a chance to reinvent himself as a multilingual speaker. Inspired by the example of a friend, who had once been an immigrant himself, Patrick set his sights on learning bits of the different languages surrounding him. His objective was to amass a repertoire of resources, a kind of linguistic toolbox which he could activate according to his needs, knowledge, and whims (cf. Lüdi/Py 2009). Rather than aiming for comprehensive competence in one (official) language, he wanted to develop a range of codes for a range of purposes. His approach thus exemplifies what Canagarajah and Wurr (2011) refer to as repertoire building.

\subsection{Learning the ropes}

When I first met them, both Ahmad and Patrick were enrolled in language courses set up by groups of volunteers. These courses were designed to provide elementary language knowledge in French in order to support learners' transition to state-sponsored language training organized by the municipalities, local associations, and the National Institute for Languages. Initially, both project participants subscribed to the view that a good command of French would provide the basis for their professional and social integration. However, as the interviews unfolded it became obvious that the "choice" to learn French was to a great extent imposed upon them: "the social agent gave me a bon for French ${ }^{1}$ but I asked for Luxembourgish and she said no, you should start with French [.... I I said okay, I want a bon for German but she said it was not possible." (August 17, 2016). The social worker's conduct could be explained by the widely held belief that French facilitates economic integration better than any other language in the local labor market (cf. Kalocsányiová 2018). Forced migrants' efforts to learn languages other than French often cause astonishment and/or are discouraged. As the above excerpt shows, Patrick expressed a strong wish to learn German (an objective shared by Ahmad). This decision was not so much related to the joint official status German enjoys in Luxembourg as to associations linking the language to the German state and its open-door refugee policy. As with Luxembourgish, both participants made efforts to learn its basics. Their initial interest in the language was spurred on by its presumed national symbolic importance; however, with the impending re-

1 Applicants for international protection receive a voucher (bon) to enroll in a language training course of their choice. 
vision of their protection status ${ }^{2}$, they began to see the value of Luxembourgish for their eventual citizenship applications as well as for current and future employment needs. Luxembourgish is an essential requirement in nearly half of the vacancies advertised in the Grand Duchy (cf. PigeronPiroth/Fehlen 2015). To give an example, Ahmad's apprenticeship application to a local HVAC contractor was formally rejected due to his insufficient competence in Luxembourgish.

The combination of French, German, and Luxembourgish indicated above also points to a desire to fit into the Grand Duchy's trilingual ideal. Both participants showed a preference for multilingual integration paths, although it must be underlined that their conscious learning efforts remained limited to the local prestige languages. Ahmad's and Patrick's interest in the other languages-ubiquitous in their immediate social environment-was rarely driven by more than common curiosity. This deserves attention for two reasons. First, because the preferred medium of communication of the people in their social circles seldom included the languages of traditional triglossia; and second, because their spontaneous language use built on elements of immigrant/minority languages that were (presumably) accumulated through informal contacts and exchanges. From the beginning of the project, both participants showed strong crosslinguistic and meta-communicative awareness. They often mentioned filling their knowledge gaps via lexical inferencing, transfers, and fluid transitions between resources that are conventionally labeled as belonging to separate languages. A promising avenue for future research would be to explore forced migrants' perception of (local) linguistic borders and their effect on processes of language acquisition. For instance, the borders that I considered relatively fixed and stable offered room for permeability and code-mixing from the participants' perspective. From our discussions, it soon became clear that it was precisely the deployment of the strategies outlined above that allowed them to engage with the multilingual social world of Luxembourg.

\section{3 "Settled" life in Luxembourg}

Two years after fleeing to Europe, both project participants claimed to be able to navigate local life with reasonable ease and success. In support of

2 Residence permits granted to beneficiaries of international protection are valid for five years. 
his position, Ahmad cited the example of ADEM (a local employment agency) to shed light on his communication strategies. He compared his communication with public officers to riding a bicycle: after his first moves (greeting) in Luxembourgish, he moves back and forth between French and English to reduce the chances of miscommunication (September 30, 2017). After completing a 9e class ${ }^{3}$, which is considered crucial for access to further studies and vocational training, Ahmad obtained an apprenticeship contract, and he has been working in the telecommunications sector since then. The combination of his old and newly acquired language resources allowed him to develop new contacts with locals and expatriates alike. Furthermore, he occasionally volunteered to interpret for his compatriots in refugee homes and health-care institutions, which indicates a growing level of confidence (and pride) in his language abilities. As discussed above, Ahmad's first encounters with Luxembourg's diversity were described as confusing, at times even hostile. His perspectives shifted significantly once his expanding multilingualism acquired value as economic and social capital and became a means of self-fulfillment.

Ahmad gained access to employment through demonstrating fluency in French; yet, from the picture he painted of his work environment ${ }^{4}$, it was certainly not the only language resource he needed. His immediate colleagues change according to the shifts he works, so we can only speculate which ethnolinguistic groups he has had the most contact with. However, the two co-workers he talked about most were described as having Portuguese origins. Ahmad's occupation requires him to work in people's homes and (at the time of writing) most of his customers belonged to the indigenous population of Luxembourg. He described one of these encounters as follows:

3 9e classes correspond to the third year of secondary education. For a period of ten months, Ahmad attended daytime classes with other (forced) migrants who did not have a recognized level of education and/or whose knowledge of languages was considered insufficient to join the mainstream training system. After successfully completing the program, he received a certificate attesting, among other things, A2 level proficiency in French and English.

4 Due to ethical and practical difficulties, it was not possible to observe Ahmad's work environment. 
A: When I need to explain how to use the decoder [...

I tell to (hesitantly) I said to the client I can explique explain in French

he told me "I'm not good in French I cannot speak well French"

I told him don't worry, don't worry me too [either] (laugh)

I'll show you it's easy (laugh). When I explained to him

he said yeah it's easy [...] (March 17, 2018)

This excerpt shows how some members of the local community can be reluctant to speak French. Past research has also dispelled the myth that all Luxembourgers are balanced trilinguals (Horner 2004) and revealed disparate attitudes toward Luxembourg's numerous ethnolinguistic groups. After this episode, I heard Ahmad suggest that his imperfect French was to his advantage that day. Indeed, it was the fear of communicating in a language which was not their native and/or preferred one that allowed the two to engage in a dialogue and defuse potential tensions. Surprisingly, Ahmad's overall impression was that customers were more likely to switch to English than to French. This analysis clearly shows that prioritizing French for its economically integrative functions is not without its tensions.

Let me return to Patrick now. After the enthusiasm of the first months, Patrick narrated his subsequent experiences as a story of downward mobility. In April 2017, I conducted ethnographic fieldwork at a professional training course for mobile application developers that he (and ten other course participants) attended. The training was sponsored by ADEM but taught by a French frontalier [cross-border worker]. The data from this fieldwork provided insights into two areas of interest in my research: the role of language(s) in Patrick's labor market integration and his experience of workplace-like communication. Let us start with the latter: although the official language of the course was English, the participants shuttled between four languages (at a minimum) to achieve their communicative aims. A careful observation of their practices confirmed what other studies had also reported (cf. Franziskus/Gilles 2012; Franziskus 2016): workplace communication in Luxembourg is reminiscent of the complexities of broader societal multilingualism and entails continuing negotiations over linguistic resources. At the time, Patrick's repertoire was adequate for accomplishing most of the content-related tasks; however, it rarely allowed him to participate in moments of humor or off-task talk. In our discussions from this period, he often represented himself as an outsider, which takes us to our second topic of interest. After meeting other job seekers at the training course, his hopes of succeeding in the local labor market diminished. On multiple occasions, he positioned himself as "a refugee who 
doesn't speak German and French very well" and stands little or no chance against the people from Luxembourg, whom he believed to be fluent in all the languages sought after in the labor market (April 7, 2017). His fears were not unfounded: an inability to perform certain combinations of French, English, German, and Luxembourgish severely limits one's chances of being considered for positions advertised in the Grand Duchy (cf. Pigeron-Piroth/Fehlen 2015).

\section{4 (Im)possibility of moving forward}

Questions of language were central to Patrick's pursuit of employment, as illustrated by this excerpt from a cover letter he drafted in the spring of 2017: "Je souhaite, afin de m'intégrer au Luxembourg, suivre des cours de luxembourgeois pour que mon activité professionnelle soit complete" ${ }^{5}$. For Patrick, unemployment constituted a barrier to his language learning progress. He saw proficiency in the "right" languages as a condition for his meaningful participation in the labor market and broader social context; as a result, he felt excluded precisely from those settings where the linguistic capital he craved could be obtained. His experience resonates with Bourdieu's observation: "Speakers lacking the legitimate competence are de facto excluded from the social domains in which this competence is required, or are condemned to silence." (1991, p. 55, emphases in original). When asked about other avenues to expand his skills, Patrick pointed to a group of customs officers and half-jokingly remarked: "do I grab a policeman to speak with me in German? They [referring to his social circle] don't have time; everyone's taking care of their own business; this is the truth." (March 12, 2018). In his search for opportunities to practice, Patrick decided to enroll in the same adult education program that Ahmad had attended the year before. Although his degree in engineering had been recognized by the Ministry for Higher Education and Research, he suddenly found himself "studying" secondary school mathematics. In addition, he was placed in an upper elementary-level English course, which contributed to tensions between his own language use and the standard of English he and his peers were expected to orient toward. In my observations, the program accentuated mat-

5 "In order to integrate in Luxembourg, I want to attend Luxembourgish classes so that my professional activities would be completed." (This translation is an approximation aimed at representing the same structural features as the original utterance.) 
ters of surface accuracy, which clashed with Patrick's (and Ahmad's) previous learning experiences, where the focus was more on meaning-making. Their language production was viewed as problematic, although both had used English for official and professional purposes before. In Blommaert's terms (2003), Patrick and Ahmad's language varieties did not "travel well"; their resources were considered functional in diverse circumstances (both before and after migration) but became dysfunctional as soon as they were placed in the context of the Grand Duchy's adult education initiatives.

Patrick's plans to move out of the refugee shelter also imploded: without an employment contract he could not apply for a lease. Instead of the upward trajectory he had hoped for (having his own place), he was again immobilized. In his reflections from this period, he circled back to the topic of languages: "everything is connected with each other, [employment] contracts and housing and languages [and] learning, sometimes I'm confused what to do, what's right" (October 28, 2017). Patrick's experience of moving downward pushes him to be active across borders and/or even remigrate within the EU. His legal status as a refugee, however, places considerable restrictions on these aspirations. Although he managed to flee to Europe, his onward movement is blocked. He is living in a state described by Carling (2002) as "involuntary immobility", which is hauntingly similar to the experiences Juffermans and Tavares (2017) documented in their research of the south-north trajectories of Luso-Africans. Patrick's wish to work, learn and move freely in Europe depends on him obtaining Luxembourgish nationality, which, as discussed earlier, requires demonstrable knowledge of the Luxembourgish language. And so, paradoxically, Patrick's escape from immobility is currently conditioned by a language the communicative reach of which is restricted to the Luxembourgish state:

P: $\quad$ this is the problem: if I'd have the nationality, I would not stay here living in Luxembourg. I would go to Belgium.

R: $\quad$ for the moment you cannot relocate $[\ldots]$

P: $\quad$ no I need to stay here for the rest of my life (laugh)

R: $\quad$ you have to stay here until?

P: $\quad$ yeah until I obtain the nationality, which is difficult. How do I learn Luxembourgish to get the nationality? This is a big problem for me [...] it makes me exhausted to think about these things

(March 12, 2018) 
In juxtaposition to French and German, the teaching and learning of Luxembourgish as a second/foreign language is fraught with complexities. For instance, the language is not used as a means of written communication by most of its speakers, except for in informal domains and new media (cf. Belling/de Bres 2014). It has also undergone major standardization in recent years, which has led to the odd situation where the Luxembourgish standard taught to immigrants (in official language courses) is not widely known among the local population. These strange circumstances severely impacted Ahmad's learning trajectory. As he showed his notes from a language course he was attending to a friend, his friend-a Luxembourger and teacher himself-labeled his laboriously acquired knowledge as incorrect, after which he "broke down and stopped" (March 9, 2017). This incident led Ahmad to withdraw from the course and discontinue his efforts to learn Luxembourgish (for a while at least). Patrick's descriptions of his learning experience with Luxembourgish revolved around the scarcity of adequate language learning tools. Recent years have certainly seen an increase in the availability of dictionaries, textbooks, and materials for selflearners, but the pool of resources is still negligible compared to the Grand Duchy's other administrative languages. Being admitted into a state-subsidized language course was not without its complications either, as the earlier discussion of Patrick's failed attempts demonstrated. In addition to being crucial for Ahmad and Patrick's citizenship applications, command of Luxembourgish also conditions access to well-paid and secure jobs in numerous domains (cf. Ehrhart/Fehlen 2011). Its significance for forced migrants' aspirations - in terms of both spatial and social mobility-indicates important directions for future research.

\section{Conclusion}

This contribution set out to scrutinize the impact of multilingualism on forced migrants' trajectories in Luxembourg. The chapter began by describing the language-migration nexus and discussing the role linguistic traits play in (de)constructing borders. After introducing the research context, the paper offered a detailed account of forced migrants' language (hi)stories. A careful analysis of divergent trajectories exposed the embodied efforts, emotions, and constraints inherent in constructing a new belonging, be it interpreted along linguistic, national, or personal lines. By foregrounding the participants' voices, the chapter shed light on forced migrants' experiences with the Grand Duchy's borders and their everyday enactments through linguistic differences. 
The discussion focused on two people who shared similar (multilayered) linguistic repertoires but reported disparate experiences. For Ahmad, the once unsettling environment evolved into a space of self-fulfillment: his expanding multilingualism has translated into enhanced opportunities for social interaction and economic advancement. By contrast, Patrick's enthusiasm for multilingualism diminished over time; despite his extensive language learning efforts, his aspirations to progress contrasted sharply with his actual experience of moving downward. While the main focus was on Ahmad's and Patrick's language lives-i.e. how the development (and deployment) of their linguistic repertoires traces, shapes, and disrupts the flow of their lives - their narratives were often intertwined with wider social discourses on integration, social alienation, and belonging. Between them, they provided rich evidence of the complexities of integration in multilingual communities. Patrick and Ahmad are also among the first beneficiaries of international protection who will be affected by the Luxembourgish Nationality Act of 2017. Because it is still a fairly recent piece of legislation, not much is known about its impact on the individual experiences of applicants or its long-term consequences. However, it does stipulate stricter testing procedures and (from a language perspective) represents a yet further move toward a "thicker" concept of belonging and citizenship. As such, it adds to the long list of contradictions that will certainly impact Ahmad's and Patrick's subsequent trajectories.

\section{References}

Anderson, Benedict (1991): Imagined Communities: Reflections on the Origin and Spread of Nationalism (rev. edn). London: Verso.

Baba, Marietta/Dahl-Jørgensen, Carla (2013): Language policy in practice: re-bordering the nation. In: International Migration 51, no. 2, p. 60-76, https://doi.org /10.1111/imig.12048.

Beine, Michel/Souy, Bénédicte (2016): The evolution of immigration and asylum policy in Luxembourg: insights from IMPALA. In: CREA Discussion Paper Series from Centre for Research in Economic Analysis. University of Luxembourg.

Belling, Luc/de Bres, Julia (2014): Digital superdiversity in Luxembourg: the role of Luxembourgish in a multilingual Facebook group. In: Discourse, Context \& Media, no. 4-5, p. 74-86, https://doi.org/10.1016/j.dcm.2014.03.002.

Blommaert, Jan (2003): Commentary: A sociolinguistics of globalization. In: Journal of Sociolinguistics 7, no. 4, p. 607-623, https://doi.org/10.1111/j.1467-9841.2 003.00244.x.

Blommaert, Jan (2010): The Sociolinguistics of Globalization. Cambridge: Cambridge University Press. 
Blommaert, Jan/Backus, Ad (2013): Superdiverse Repertoires and the Individual. In: de Saint-Georges, I./Weber, J.-J. (eds.): Multilingualism and Multimodality: Current Challenges for Educational Studies. Rotterdam: Sense, p. 11-32.

Bourdieu, Pierre (1991): Language and symbolic power. Cambridge, MA: Harvard University Press.

Burke, Peter (2004): Epilogue: languages and nations. In: Burke, P.: Language and Communities in Early Modern Europe. Cambridge: Cambridge University Press.

Busch, Brigitta (2012): The Linguistic Repertoire Revisited. In: Applied Linguistics 33, no. 5, p. 503-523, https://doi.org/10.1093/applin/ams056.

Busch, Brigitta (2017): Expanding the Notion of the Linguistic Repertoire: On the Concept of Spracherleben - The Lived Experience of Language. In: Applied Linguistics 38, no. 3, p. 340-358, https://doi.org/10.1093/applin/amv 030.

Canagarajah, Suresh (ed.) (2017): The Routledge handbook of migration and language. Oxon: Routledge.

Canagarajah, Suresh/Wurr, Adrian J. (2011): Multilingual Communication and Language Acquisition: New Research Directions. In: The Reading Matrix 11, no. 1, p. 1-15.

Carling, Jørgen (2002): Migration in the age of involuntary immobility: theoretical reflections and Cape Verdean experiences. In: Journal of Ethnic and Migration Studies 28, no. 1, p. 5-42, https://doi.org/10.1080/13691830120103912.

Carling, Jørgen/Collins, Francis (2018): Aspiration, desire and drivers of migration. In: Journal of Ethnic and Migration Studies 44, no. 6, p. 909-926, https://doi.org /10.1080/1369183X.2017.1384134.

Creese, Angela/Blackledge, Adrian (2010): Translanguaging in the Bilingual Classroom. A Pedagogy for Learning and Teaching. In: The Modern Language Journal 94, no. 1, p. 103-115, https://doi.org/10.1111/j.1540-4781.2009.00986.x.

de Bres, Julia (2014): Competing language ideologies about societal multilingualism among cross-border workers in Luxembourg. In: International Journal of the Sociology of Language, no. 227, p. 119-137, https://doi.org/10.1515/ijsl-2013 $-0091$.

de Fina, Anna/Tseng, Amelia (2017): Narrative in the study of migrants. In: Canagarajah, S. (ed.): The Routledge handbook of migration and language. Oxon: Routledge, p. 381-396.

Duchêne, Alexandre/Heller, Monica (eds.) (2012): Language in Late Capitalism: Pride and Profit. New York: Routledge.

Ehrhart, Sabine/Fehlen, Fernand (2011): Luxembourgish: A Success Story? A Small National Language in a Multilingual Country. In: Fishman, J. A./García, O. (eds.): Handbook of Language and Ethnic Identity: the success-failure continuum in language and ethnic identity efforts. Oxford: Oxford University Press, p. 285-298.

Faist, Thomas (2013): The mobility turn: a new paradigm for the social sciences? In: Ethnic and Racial Studies 36, no. 11, p. 1637-1646, https://doi.org/10.1080/0 1419870.2013.812229. 
Franziskus, Anne (2016): 'One does not say Moien, one has to say Bonjour': Expressing Language Ideologies through Shifting Stances in Spontaneous Workplace Interactions in Luxembourg. In: Journal of Linguistic Anthropology 26, no. 2, p. 204-221, https://doi.org/10.1111/jola.12124.

Franziskus, Anne/Gilles, Peter (2012): 'Et le präis direct etikett?' Non-overlapping repertoires in workplace communication in Luxembourg. In: Sociolinguistica: Internationales Jahrbuch für Europäische Soziolinguistik, no. 26, p. 58-71.

García, Ofelia/Wei, Li (2014): Translanguaging: Language, Bilingualism and Education. Basingstoke: Palgrave.

Gogonas, Nikos/Kirsch, Claudine (2016): 'In this country my children are learning two of the most important languages in Europe': ideologies of language as a commodity among Greek migrant families in Luxembourg. In: International Journal of Bilingual Education and Bilingualism 21, no. 4, p. 426-438, https://d oi.org/10.1080/13670050.2016.1181602.

Glick Schiller, Nina (2009): A Global perspective on Transnational Migration: Theorizing Migration without Methodological Nationalism. www.compas.ox.ac.uk/ media/WP-2009-067-Schiller_Methodological_Nationalism_Migration.pdf, 28/4/2018.

Grzymala-Kazlowska, Aleksandra/Phillimore, Jenny (2018): Introduction: rethinking integration. New perspectives on adaptation and settlement in the era of super-diversity. In: Journal of Ethnic and Migration Studies 44, no. 2, p. 179-196, https://doi.org/10.1080/1369183X.2017.1341706.

Heller, Monica (1987): The role of language in the formation of ethnic identity. In: Phinney, J./Rotheram, M. J. (eds.): Children's Ethnic Socialisation: Pluralism and Development. Newbury Park: Sage, p. 180-200.

Heller, Monica (2010): The Commodification of Language. In: Annual Review of Anthropology, no. 39, p. 101-114.

Horner, Kristine (2004): Negotiating the language-identity link: media discourse and nation building in Luxembourg. PhD dissertation, State University of New York at Buffalo.

Horner, Kristine (2009): Regimenting language, mobility and citizenship in Luxembourg. In: Extra, G./Spotti, M./van Avermaet, P. (eds.): Language testing, migration and citizenship: cross-national perspectives on integration regimes. London: Continuum, p. 148-166.

Horner, Kristine (2017): Language regimes and acts of citizenship in multilingual Luxembourg. In: Milani, T. M. (ed.): Language and citizenship. Broadening the agenda. Amsterdam: John Benjamins, p. 41-63.

Horner, Kristine/Weber, Jean-Jacques (2008): The language situation in Luxembourg. In: Current Issues in Language Planning 9, no. 1, p. 69-128, https://doi.o rg/10.2167/cilp130.0.

Irvine, Judith T./Gal, Susan (2000): Language ideology and linguistic differentiation. In: Kroskrity, Paul V. (ed.): Regimes of Language: Ideologies, Polities, and Identities. Santa Fe: School of American Research Press, p. 35-84. 
Jørgensen, Jens Normann/Karrebæk, Martha/Madsen, Lian Malai/Møller, Janus Spindler (2011): Polylanguaging in Superdiversity. In: Diversities 13, no. 2, p. 22-37.

Juffermans, Kasper/Tavares, Bernardino (2017): South-North trajectories and language repertoires. In: Kerfoot, C./Hyltenstam, K. (eds.): Entangled Discourses: South-North Orders of Visibility. New York: Routledge, p. 99-115.

Kalocsányiová, Erika (2017): Towards a Repertoire-Building Approach: Multilingualism in Language Classes for Refugees in Luxembourg. In: Language and Intercultural Communication 17, no. 4, p. 474-493, https://doi.org/10.1080/14708 477.2017.1368149.

Kalocsányiová, Erika (2018): At the borders of languages: the role of ideologies in the integration of forced migrants in multilingual Luxembourg. In: Journal of Ethnic and Migration Studies, https://doi.org/10.1080/1369183X.2018.1510307.

Kusenbach, Margarethe (2003): Street phenomenology: the go-along as ethnographic research tool. In: Ethnography 4, no. 3, p. 455-485, https://doi.org/10.11 77/146613810343007.

Lamarre, Patricia (2013): Catching 'Montréal on the Move' and Challenging the Discourse of Unilingualism in Québec. In: Anthropologica 55, no. 1, p. 41-56.

Lüdi, Georges/Py, Bernard (2009): To be or not to be ... a plurilingual speaker. In: International Journal of Multilingualism 6, no. 2, p. 154-167, https://doi.org/10. 1080/14790710902846715.

Newman, David (2006): The lines that continue to separate us: borders in our "borderless" world. In: Progress in Human Geography 30, no. 2, p. 143-161.

OP (Office for official publications of the European Communities) (1973): Declaration on European Identity. In: Bulletin of the European Communities, no. 12, p. $118-122$.

Otsuji, Emi/Pennycook, Alastair (2010): Metrolingualism: fixity, fluidity and language in flux. In: International Journal of Multilingualism 7, no. 3, p. 240-254, https://doi.org/10.1080/14790710903414331.

Park, Joseph Sung-Yul (2014): Cartographies of language: Making sense of mobility among Korean transmigrants in Singapore. In: Language and Communication, no. 39, p. 83-91, https://doi.org/10.1016/j.langcom.2014.09.001.

Pigeron-Piroth, Isabelle/Fehlen, Fernand (2015): Les langues dans les offres d'emploi au Luxembourg (1984-2014). University of Luxembourg.

Rodgers, Graeme (2004): "Hanging Out" with Forced Migrants: Methodological and Ethical Challenges. Forced Migration Review, no. 21, p. 48-49.

Shohamy, Elana (2006): Language policy: hidden agendas and new approaches. London: Routledge.

Silverstein, Michael (2014): How Language Communities Intersect: Is "superdiversity" an incremental or transformative condition? www.tilburguniversity.edu/ upload/89a37ed3-3c2d-4d2b-bfb3-e907550f38f0_TPCS_107_Silverstein.pdf, $30 / 04 / 2018$. 
STATEC (2018a): Etat de la population. www.statistiques.public.lu, 15/9/2018

STATEC (2018b): Emploi salarié intérieur par lieu de résidence et nationalité 1995-2018. www.statistiques.public.lu, 15/9/2018.

Stevenson, Patrick (2006): National Languages in Transnational Contexts: Language, Migration and Citizenship in Europe. In: Mar-Molinero, C./Stevenson, P. (eds.): Language Ideologies, Policies and Practices: Language and the Future of Europe. Basingstoke: Palgrave Macmillan, p. 147-161.

Stevenson, Patrick (2014): Language (hi)stories: researching migration and multilingualism in Berlin. In: Horner, K./de Saint-Georges, I./Weber, J.-J. (eds.): Multilingualism and mobility in Europe: policies and practices. Frankfurt am Main: Peter Lang, p. 265-280.

Stevenson, Patrick (2017): Language and Migration in a Multilingual Metropolis: Berlin Lives. Cham: Palgrave Macmillan, https://doi.org/10.1007/978-3-319-4060 6-0.

Van Avermaet, Piet (2009): Fortress Europe? Language policy regimes for immigration and citizenship. In: Hogan-Brun, G./Mar-Molinero, C./Stevenson, P. (eds.): Discourses on Language and Integration: critical perspectives on language testing regimes in Europe. Amsterdam: John Benjamins, p. 15-44.

Van Avermaet, Piet/Rocca, Lorenzo (2013): Language testing and access. Exploring language frameworks. In: Studies in Language Testing, no. 36, p. 11-44.

Vertovec, Steven (2007): Super-Diversity and its Implications. In: Ethnic and Racial Studies, 30, no. 6, p. 1024-1054, https://doi.org/10.1080/01419870701599465.

\section{About the author}

Erika Kalocsányiová | University of Luxembourg | Campus Belval, Maison des Sciences Humaines | FLSHASE - Research on Multilingualism | 11, Porte des Sciences | 4366 Esch/Alzette | Luxembourg | T +352 4666445146 | erika.kalocsanyiova@uni.lu

Sociolinguistics, doctoral researcher; research interests: multilingualism, linguistic integration and language learning in contexts of forced migration

\section{Acknowledgements}

I would like to thank the participants for sharing their time and insights with me. Thanks are extended to Sabine Ehrhart and the editors for their thoughtful comments on previous drafts. Any inaccuracies remain my sole responsibility. 